\title{
Mental Health Online
}

Citation for published version (APA):

Egher, C. (2019). Mental Health Online: The enactment of expertise on Bipolar disorder on American and French online platforms. [Doctoral Thesis, Maastricht University]. ProefschriftMaken Maastricht. https://doi.org/10.26481/dis.20191204ce

Document status and date:

Published: 01/01/2019

DOI:

10.26481/dis.20191204ce

Document Version:

Publisher's PDF, also known as Version of record

\section{Please check the document version of this publication:}

- A submitted manuscript is the version of the article upon submission and before peer-review. There can be important differences between the submitted version and the official published version of record.

People interested in the research are advised to contact the author for the final version of the publication, or visit the DOI to the publisher's website.

- The final author version and the galley proof are versions of the publication after peer review.

- The final published version features the final layout of the paper including the volume, issue and page numbers.

Link to publication

\footnotetext{
General rights rights.

- You may freely distribute the URL identifying the publication in the public portal. please follow below link for the End User Agreement:

www.umlib.nl/taverne-license

Take down policy

If you believe that this document breaches copyright please contact us at:

repository@maastrichtuniversity.nl

providing details and we will investigate your claim.
}

Copyright and moral rights for the publications made accessible in the public portal are retained by the authors and/or other copyright owners and it is a condition of accessing publications that users recognise and abide by the legal requirements associated with these

- Users may download and print one copy of any publication from the public portal for the purpose of private study or research.

- You may not further distribute the material or use it for any profit-making activity or commercial gain

If the publication is distributed under the terms of Article $25 \mathrm{fa}$ of the Dutch Copyright Act, indicated by the "Taverne" license above, 
Summary 


\section{SUMMARY}

In Western societies, expertise currently shapes people's lives to a significant degree, as people seek expert advice on a growing number of issues, such as how to avoid incurring financial debt, how to collaborate with colleagues with different personalities, how to maintain a healthy diet, or even how to select one's partner. Not only is there more expertise in our societies, but there are also more people who claim expertise as their prerogative. They do so not only due to having followed specific professional trajectories themselves and having received official accreditations, but increasingly by invoking various combinations of insights, skills, and experiences. At the same time, however, the relevance of expertise and the authority of experts have been intensely challenged. Thus, some have questioned the scientific grounds and the level of certainty based on which experts make their recommendations. Others have criticized the process of making decisions based on expert advice as undemocratic, arguing that experts as a specific social group are either detached from the realities of life and the preferences of the populations which become subject to their decisions, or that they are self-interested and primarily seek to maintain or further their already privileged position. Nowadays expertise is therefore both widely distributed and very much challenged.

This state of affairs is particularly poignant in the field of mental health, where medical knowledge and therapeutic approaches have been challenged both from within and from without the medical establishment, and where relations between people diagnosed and medical professionals have been rather contentious. The internet has generated various opportunities but also new challenges in this respect, as it has been increasingly used for the search and provision of mental health-related information, and as it has allowed people with the same diagnoses to come together, irrespective of their location. This has given rise to a set of intriguing questions about the identity of internet users who share and contribute to the development of knowledge, about the ways in which various aspects of their identity influence their online practices, and about the relations they develop with others who claim to have knowledge on the same topic, but from different perspectives.

In this dissertation I have studied how expertise on bipolar disorder is enacted on different American and French online platforms. In so doing, I have joined a long tradition of STS scholars, who have shown that knowledge is importantly shaped by the tools and instruments used in its development as well as by the norms and values of the communities of practice involved. I have combined these insights with perspectives acquired from medical sociologists and media scholars, who have focused on how the roles of patients and medical professionals have changed as a consequence of recent social 
developments. A series of top-down and bottom-up initiatives has encouraged citizens to become informed about their health, and to play an active role in its management by taking on healthier lifestyles, by using various (wearable) technologies to keep track of health-related data, and by developing collaborative relationships with medical professionals. The internet has figured prominently in these initiatives as a therapeutic and as an educational tool, because it allows for the provision of online therapies, and because it affords quick and easy access to large amounts of information. It also enables people to contribute to new knowledge through various sharing practices, and many believe(d) that it would lead to the flattening of cultural differences.

This medium's potential has led many enthusiasts to assume that it will empower patients and enhance their engagement in knowledge processes, that it will improve relations between patients and medical professionals by facilitating communication between them, that it will help increase the popularity and authority of public institutions by facilitating transparency, accountability, and public dialogue. More recent studies on the role of the internet in mental health-related practices have revealed, however, a much more nuanced picture and have highlighted the need for more specific insights into how people in different functions and positions engage with the various technologies available online to make their knowledge on a particular mental health condition manifest. That is why this dissertation focuses on the following (sub)questions: (1) How do different stakeholders engage with online technologies to enact expertise about bipolar disorder? (2) How does the use of the internet in processes of knowledge evaluation and production allow for people diagnosed with bipolar disorder to re-position themselves in relation to medical professionals? (3) How do cultural markers shape the online enactment of expertise about bipolar disorder? (4) What individualizing or collectivity-generating effects does the internet have in relation to the online enactment of expertise about bipolar disorder?

I have answered these questions by collecting and analyzing online materials provided by two types of stakeholders: governmental agencies and people diagnosed with bipolar disorder in the U.S. and France. This approach has allowed me to bring into better relief how different types of constraints and resources shape the online enactment of expertise. Data were collected at different moments between June 2014 and September 2018 from different online platforms: official online pages of state agencies, blogs, and fora. In selecting the platforms, I aimed to reproduce the behaviors of average internet users interested in mental health-related information. I used the Google index as a relevance indicator and only selected online platforms which did not require any fee or registration to be accessed. The data consist of online texts, including hyperlinks and images, and have been analyzed using (combinations of) thematic analysis, computermediated discourse analysis, and conversation analysis. 
In the introductory chapter, I explain why it is important to study expertise at this particular moment in time, focusing on the ways in which its meaning and relevance have been recently transformed and challenged. I also highlight the importance of understanding how the internet shapes the production, circulation, and evaluation of knowledge, and indicate what is specific about mental health and bipolar disorder to warrant a focused study thereof in relation to expertise. Furthermore, the main ways in which the concept of expertise has been approached in philosophy, sociology, and psychology are described. I build upon these theoretical perspectives using new insights acquired through the analysis of the data collected in order to develop a new approach to expertise. I understand expertise as a collective and practical achievement realized through coordination among stakeholders endowed with different types of knowledge, who occupy multiple, shifting positions in a complex ecosystem. This perspective has the advantage of drawing attention to the various interests and the multiple identities of a single individual and to the ways in which these may shape his/her contribution to the development of expertise. It also expands this concept, as it broadens the focus from relations between people who have expertise and people who need the advice and support of those who have it, to also include the relations that develop between people endowed with different types of expertise, who need to come together to solve problems which transcend the domains of their individual expertise and who, in so doing, may facilitate the development of a new type of expertise. The chapter concludes with a description of the methodological approach at the heart of this study and a reflection on some ethical issues I have encountered while conducting it.

In chapter two I show how two governmental agencies - the National Institute of Mental Health (NIMH) in the U.S. and La Haute Autorité de Santé (HAS) in Franceenact expertise about bipolar disorder. These are highly authoritative institutions, which shape the ways in which bipolar disorder is understood by medical professionals, people diagnosed and the interested public. Even though they have considerable resources, which would allow them to deploy most online technologies available, these agencies face regulatory and socio-economic constraints, which limit their use of digital technologies. While both in the U.S. and France, the internet has been approached as a cost-effective means to provide mental health-related information, NIMH and HAS face two important challenges. First, in sharing their insights, they need to respect the accessibility recommendations for people with disabilities and for those using oldergeneration or less sophisticated technologies. Second, they need to take into account a social, professional, and cultural climate, where psychiatric approaches continue to be criticized, and where important struggles take place between different types of mental health professionals. To understand how these governmental agencies manage to convincingly enact expertise about bipolar disorder online, I have used an innovative methodological framework, which has allowed me to approach their online platforms as 
a complex set of public performances. The findings reveal that both NIMH and HAS are reluctant internet users, which have opted for noninteractive online platforms and static digital tools, such as pdf files and online text. In so doing, both agencies depict the knowledge currently available on bipolar disorder as precise and stable, all the while making several significant changes in the conceptualization of this condition. Thus, whereas the performative techniques they use are similar, NIMH and HAS differ in the aspects they choose to focus on in relation to bipolar disorder. I argue that this difference is informed by the distinct goals they need to address, as a consequence of the significant reforms undertaken in the mental healthcare system of their respective countries.

Chapter three marks a switch in focus, concentrating on people diagnosed with bipolar disorder and the different ways in which they enact expertise online. I show that medical perspectives on the effectiveness of therapeutic approaches used for this condition find their way from scientific publications to the (potential) recipients of such treatments, who transform them through their online engagements. This view is based on the analysis of two types of materials: highly-cited academic articles and abstracts, and online contributions provided by people diagnosed with bipolar disorder on blogs and fora. The findings show that the latter re-appropriate the notions of uncertainty, complexity, and individualization, which characterize current medical perspectives on the treatment of bipolar disorder, to achieve various pragmatic goals. The online affordances of blogs and fora allow for the longitudinal accumulation of numerous insights in the same online spaces. This, I argue, means that people diagnosed with bipolar disorder can move beyond the enactment of lay expertise and contribute to the development of what I have termed "digitally-informed hypotheses" about treatment effectiveness. Yet, for these hypotheses to lead to the development of the kind of insights that medical professionals take into account in their prescription practices, they need to be taken up by scientists. This shows that the degree to which people diagnosed with bipolar disorder can re-position themselves in relation to medical professionals through such contributions remains limited.

Chapter four examines the online and offline activities of two individual bloggers. At a time when people are urged to become informed about their health and to assume personal responsibility for it, I show how these bloggers have been able to become highly influential through their skillful use of the internet. By acquiring and enacting interactional expertise, they have managed to develop important ties with many other people diagnosed with bipolar disorder, who are avid readers of their blogs, as well as with medical professionals. On the one hand, their diagnosis has conferred them with legitimacy among people diagnosed and their families. Combined with their 
skillful use of the internet, this has enabled them to attract vast audiences. On the other hand, through the substantial medical knowledge they have acquired and due to their tremendous online popularity, they have successfully positioned themselves as representatives of people diagnosed with bipolar disorder and have become interesting collaborators for scientists and medical professionals. I argue that due to these various attributes and to the mediation work they engage in between people diagnosed and medical professionals, these bloggers have turned themselves into a new type of stakeholder, what I have called "online expert mediators". The high standing they enjoy is unprecedented among people diagnosed with bipolar disorder who lack medical training. Yet, this influential position has not been acquired through a subversive use of the internet, but through the strategic alliances these bloggers have forged with "traditional" experts. By studying how they enact interactional expertise, this chapter also makes a theoretical contribution, as it shows that this concept has a stronger bidirectional character than its proponents (Collins \& Evans, 2002) have suggested, and as it highlights the important effects the medium has on the ways in which this specific type of expertise is made manifest.

In chapter five I scrutinize how current tendencies to focus on the healthrelated aspects which make people different rather than similar and the dominant incentives to responsibilize individuals about their health affect the development of lay expertise. This is important, because lay expertise is a collective concept, that depends for its development on the willingness of people diagnosed to share their insights with others with the same diagnosis. It is acquired as individuals learn to combine medical perspectives with knowledge developed through reflection on their personal experiences and from the strategies other people share. By studying the behaviors of online contributors diagnosed with bipolar disorder, I show that they enact solidarity with others with whom they share important commonalities. In so doing, they develop a new type of subgroup that I have termed "digital biocommunities". These communities come into being as people are brought together by a common diagnosis as well as by an increasing number of other relevant similarities, such as personal values and preferences and a common idiom of practice regarding their engagements with the technologies of online fora. While this shows that the internet has enabled the development of a new collective in relation to the enactment of expertise, digital biocommunities are based on practices of inclusion and exclusion. The findings presented in this last empirical chapter further reveal that the enactment of solidarity and lay expertise are closely linked, as online contributors incur various costs and perform affective labor in order to share their knowledge with those in need of it. Thus, not only do different individuals position themselves as lay experts in specific contexts, but they also contribute to the collective development of lay expertise, as new knowledge is distilled from their various sharing practices. A noteworthy contribution that this dissertation therefore makes is to show that 
despite fears that too strong a focus on individualization in healthcare would jeopardize solidarity, people diagnosed continue to understand and make sense of their condition relationally, through exchanges with various people in their lives. Furthermore, through their online exchanges, they manage to renounce, if only momentarily, the identity of vulnerable people, in need of assistance, and to reveal, instead, their ability to help and support others.

In the concluding chapter I reflect upon the significance of these findings by considering them against the backdrop of current developments in data analytics and artificial intelligence. Enthusiastic supporters of the latter believe algorithms and digital technologies may usurp the privileged positions humans have had for so long in the development of knowledge, thereby casting doubt about the meaning and relevance of human expertise. This dissertation has shown, however, that contrary to such expectations, context sensitivity and affective labor play an important role in the development and enactment of expertise. Substantial knowledge of bipolar disorder has had to be combined by online contributors with relevant insights about socio-cultural and personal factors. Thus, people diagnosed with this condition have made sense of it in ways which are shaped by how mental healthcare is organized in the countries they inhabit, by what medical professionals, family members, employers and friends expect of them, and by the aspects of their lives they find valuable and want to uphold despite their illness. The findings presented here have also shown that expertise bears the marks of important norms and values.

Many scholars and social commentators have feared that the incentives to responsibilize people for their health may prompt them to approach the provision of healthcare based on merit. An important contribution of this dissertation is to have shown instead that many online contributors derive important feelings of wellbeing from their ability to support others, that sharing one's plight online makes it more bearable. Solidarity is therefore a value worth further investigation in relation to the development and enactment of expertise. More consideration also needs to be given to the affective practices involved in the production of epistemic claims and expert recommendations, as the findings presented in this study have revealed how important emotional management is for interactions involving many people, who are endowed with different types of knowledge, who have different needs, and who pursue various goals.

Another significant contribution that this dissertation has made is to highlight how influential cultural factors remain when expertise about bipolar disorder is enacted online. By comparing French and American stakeholders, the analysis has revealed a number of important similarities and differences. Thus, both governmental agencies 
studied here have used similar performative techniques on their online platforms, and people diagnosed with bipolar disorder from both countries have contributed to the development of what I have called "digitally-informed hypotheses". They have also engaged in solidaristic practices. Nonetheless, the findings have also revealed that whereas online contributors in the U.S. prefer to share their insights on blogs, in France online fora are much more popular. While this may be due to the varying level of online visibility of the blogs and fora studied, more research is needed to better understand what accounts for such differences. Encouragements for people to become actively engaged in the management of their health combined with the possibility for them to become producers of health-related information through the use of interactive online platforms has led to the development of a new and highly successful type of entrepreneurs in the U.S., which I have called "online expert mediators". The absence of this form of entrepreneurial subjectivity from the French online mental health landscape may be due to a less pronounced focus on individual entrepreneurialism in France or to the fact that French medical professionals have managed to retain their authority and to maintain more cordial relations with patients. Another important cultural distinction that this dissertation has highlighted refers to different approaches and orientations to bipolar disorder. The two governmental agencies studied have re-conceptualized bipolar disorder in different ways, one promoting a neurological understanding and the other emphasizing its degenerative and highly suicidal character. Whereas many French online contributors diagnosed with this condition engaged in online exchanges to learn to better manage this condition in the context of rich professional and personal lives, many online participants in the U.S. were unemployed or had a hard time retaining their jobs. Furthermore, the latter seemed to have more fraught family relations and to be engaged in fewer social activities offline than their French counterparts. More studies are therefore needed to understand what accounts for these social differences on bipolar disorder and what measures would be most effective in addressing them.

Overall, this dissertation has shown that the online enactment of expertise is not a straightforward process, whereby offline practices and approaches are easily uploaded onto various online spaces, but it requires a lot of work, new skills and, at times, new or different collaborations between multiple stakeholders. Many have hoped that the internet would enhance the engagement of people diagnosed and enable them to develop more balanced relations with medical professionals, but the findings presented here suggest that such options are available only to some individuals and only in certain contexts. They have shown, however, that people diagnosed engage in more nuanced ways with the medical insights available to them, as they do not merely accept them as authoritative or automatically resist them. Instead, they re-appropriate them in creative ways, they adapt them to their particular goals and preferences. Furthermore, the internet has facilitated the development of a broad variety of exchanges, from rather brief and 
fleeting interactions among individuals interested in a few specific topics, to the rise of the highly popular and influential online expert mediators, to the development of digital biocommunities among people brought and held together by a growing number of commonalities.

The internet has been approached by many as a quick technological fix, as a medium through which mental health-related information and care could be provided in a cost-effective way to a large number of people. Yet, the findings presented here have shown that such approaches are bound to fail, if the social and cultural context in which the internet is to be used is not given sufficient consideration. At the same time, this dissertation indicates that fears that the use of the internet would have negative consequences on the health and wellbeing of people diagnosed by exposing them to inaccurate information and/or by increasing the risks of contentious relations with their medical professionals are not always well-founded. This does not mean, however, that this medium does not continue to pose important challenges. New approaches and policies are required in order to better tackle them, and these can mainly be developed by paying attention to the specific ways in which different types of users engage with the online affordances of various platforms. Furthermore, for the internet to achieve its potential in furthering patient engagement and improving the quality of their relations with medical professionals, important changes in the behaviors of relevant stakeholders need to occur. While people diagnosed need to become more familiar with scientific approaches and methodology, scientists and medical professionals have to be granted the time and opportunity to work on developing closer relations with their patients and study participants. The findings presented in this dissertation suggest that people diagnosed can handle numerous sources of ambiguity and can accept lower thresholds for the effectiveness of treatment, if the manner in which they are informed about them is not paternalistic and dismissive, but constitutes, instead, an open invitation to dialogue. 



\section{Samenvatting}




\section{SAMENVATTING}

In het westen beïnvloedt expertise het leven van mensen in vergaande mate. Mensen schakelen de hulp in van experts voor een groeiend aantal problemen, waaronder het voorkomen van schulden, het volgen van een dieet, en het vinden van een partner. Vandaag de dag is er niet alleen meer expertise in onze samenleving, maar zijn er ook meer mensen die het claimen van expertise als hun recht zien. Zij doen dit niet alleen op basis van een opleiding die hen bepaalde rechten verleend, maar ook op basis van variërende combinaties van inzichten, vaardigheden en ervaringen. Tegelijkertijd worden de expertise en het gezag van experts in toenemende mate betwist en de wetenschappelijke gronden en het niveau van zekerheid waarop experts hun aanbevelingen doen ter discussie gesteld. Anderen stellen dat het besluitvormingsproces van experts ondemocratisch is en beargumenteren dat experts ver af staan van het dagelijks leven en de voorkeuren van de mensen die het effect van hun beslissingen moeten ondergaan. Daarnaast worden deze experts verweten dat ze alleen geïnteresseerd zijn in het verbeteren van hun reeds bevoorrechte positie. Tegenwoordig is expertise dus niet alleen wijdverspreid, maar staat het ook ter discussie.

Bovenstaande situatie is met name schrijnend in het domein van de geestesziekten, waar medische kennis en therapieën onder vuur liggen door mensen van zowel de gevestigde medische orde als daarbuiten, en waar de relatie tussen gediagnostiseerden en medische professionals omstreden is. Het internet heeft hiervoor zowel nieuwe mogelijkheden als uitdagingen opgeleverd. Het is gebruikelijk geworden om informatie over geestesziekten op het internet op te zoeken en aan te bieden. Daarnaast biedt het internet mensen met een soortgelijke diagnose de mogelijkheid samen te komen, ongeacht waar zij zich ter wereld bevinden. Dit leidt tot een aantal intrigerende vragen over de identiteit van internetgebruikers die bijdragen aan het ontwikkelen en delen van kennis, over hoe de verschillende aspecten van hun identiteit hun online gedrag beïnvloeden, en over de relaties die zij aangaan met andere personen die beweren kennis te bezitten over het zelfde onderwerp vanuit verschillende perspectieven.

In dit proefschrift heb ik bestudeerd hoe expertise op het gebied van bipolaire stoornissen vorm krijgt op verschillende Amerikaanse en Franse online platformen. Hiermee volg ik een traditie van STS-onderzoekers, die aangetoond hebben dat kennis vormgegeven wordt door de hulpmiddelen en instrumenten die gebruikt worden tijdens haar ontwikkeling, alsmede door de normen en waarden van de gemeenschappen die bij de ontwikkeling van deze kennis betrokken zijn. Ik heb deze inzichten gecombineerd met de perspectieven van medisch sociologen en mediawetenschappers, die onderzocht hebben hoe de rollen van patiënten en beroepsmedici veranderd zijn als gevolg van 
recente sociale ontwikkelingen. Diverse top-down en bottom-up initiatieven hebben burgers aangemoedigd informatie over hun gezondheid in te winnen, en om hier actief aan te werken door gezonder te leven, door informatie in te winnen door middel van nieuwe technologieën, en door samen te werken met medici. Het internet speelt een prominente rol hierin, als een therapeutisch en een educatief hulpmiddel, aangezien het niet alleen online therapieën aanbiedt maar ook snel en gemakkelijk toegang verschaft tot grote hoeveelheden informatie. Dit stelt mensen ook in staat bij te dragen aan nieuwe kennis door het delen van informatie. Velen zijn van mening dat dit tot een afvlakking van culturele verschillen zal leiden.

Voorstanders van dit nieuwe medium veronderstellen dat het de potentie heeft patiënten te emanciperen en hun betrokkenheid bij kennisprocessen zal vergroten. Daarnaast zou het de betrekkingen tussen patiënten en medici verbeteren en de communicatie tussen hen vergemakkelijken. Bovendien zou meer transparantie, verantwoordingsplicht, en publieke dialoog het gezag en de populariteit van openbare intstellingen bevorderen. Recent onderzoek naar de rol van het internet in geestelijk gezondheidszorgpraktijken laat echter een genuanceerder beeld zien. Deze studies benadrukken de noodzaak voor meer specifieke inzichten in hoe mensen in verschillende functies en posities diverse beschikbare online technieken gebruiken om kennis te vergroten over hoe een bepaalde geestesziekte zich manifesteert. Daarom stelt dit proefschrift de volgende (sub)vragen: (1) Hoe gebruiken verschillende belanghebbenden online technieken om expertise over bipolaire stoornissen aan te tonen? (2) Hoe stelt het gebruik van het internet bij het evalueren en produceren van kennis mensen (bij wie een bipolaire stoornis is vastgesteld) in staat om zich te herpositioneren vis-a-vis medici? (3) Hoe beïnvloeden culturele verschillen de manieren waarop expertise over bipolaire stoornis online wordt uitgeoefend? (4) Welke individualiserende of gemeenschapsvormende effecten heeft het internet als het op het het online uitoefenen van expertise over bipolaire stoornis aankomt?

Ik heb deze vragen beantwoord door het vergaren en analyseren van online bronnen die door twee soorten belanghebbenden werden aangeboden: overheidsinstanties en mensen bij wie bipolaire stoornis is vastgesteld in Amerika en in Frankrijk. Deze aanpak heeft mij in staat gesteld te tonen hoe verschillende middelen en beperkingen de online manifestatie van expertise beïnvloeden. De data is op verschillende tijdstippen tussen juni 2014 en september 2018 verzameld op diverse online platforms: officiële webpagina's van overheidsinstellingen, blogs, en fora. Bij het selecteren van de platforms heb ik geprobeerd het gedrag van de gemiddelde internetgebruiker die een interesse heeft in informatie over geestesziekten te reproduceren. Ik heb Google index gebruikt om een indicatie te krijgen van de relevantie van diverse platformen, en vervolgens heb ik enkel online platformen geselecteerd die geen registratie of betaald lidmaatschap vereisten. 
De verzamelde data bestaat uit online teksten inclusief hyperlinks en afbeeldingen, en deze is geanalyseerd door (combinaties van) thematische analyse, computer geassisteerde discussie analyse, en conversatie analyse.

In de introductie leg ik uit waarom het belangrijk is om juist nu expertise te bestuderen, met een focus op de wijze waarop de betekenis en relevantie van expertise onlangs getransformeerd is en bekritiseerd wordt. Ik benadruk ook hoe belangrijk het is inzicht te verkrijgen in hoe het internet kennis vervaardigt, distribueert en doorontwikkelt, en ik leg uit wat geestesziekten en bipolaire stoornissen zo bijzonder maakt om er een onderzoek naar expertise aan te wijden. Verder beschrijf ik de voornaamste manieren waarop het concept expertise benaderd wordt in de filosofie, sociologie, en psychologie. Ik bouw voort op deze theoretische perspectieven en analyseer de verzamelde data om nieuwe inzichten te vergaren en een nieuwe benadering van expertise te formuleren. Ik zie expertise als een collectieve en praktische prestatie die het resultaat is van coördinatie tussen belanghebbenden met verschillende vormen van kennis, die meerdere verschuivende posities innemen in een complex ecosysteem. Dit perspectief heeft als voordeel dat de aandacht uitgaat naar de verschillende interesses en identiteiten van een individu, en hoe deze zijn of haar bijdrage aan het ontwikkelen van expertise vormgeeft. Dit perspectief is tevens een uitbreiding van het concept expertise, omdat het de focus verbreedt. Het kijkt niet alleen naar mensen met expertise en mensen die advies en ondersteuning van mensen met expertise nodig hebben, maar het richt onze blik ook op de relaties die zich vormen tussen experts van verschillende pluimage, die samen moeten werken om problemen op te lossen die hun individueel vakgebied overstijgen en die hiermee de ontwikkeling van een nieuw type expertise faciliteren. Het hoofdstuk sluit af met een beschrijving van de methodologische aanpak van deze studie en een reflectie op enkele ethische problemen die ik ondervond tijdens mijn onderzoek.

In hoofdstuk twee laat ik zien hoe twee overheidsinstanties - the National Institute of Mental Health (NIMH) in de Verenigde Staten, en La Haute Autorité de Santé (HAS) in Frankrijk - expertise met betrekking tot bipolaire stoornis bepalen. Dit zijn instituten met veel gezag, die de manier waarop bipolaire stoornis begrepen wordt door medici, patiënten, en een breder gë̈nteresseerd publiek vormgeeft. Hoewel zij beschikken over voldoende middelen, worden deze instanties beperkt door wetgeving en socio-economische factoren, die hun gebruik van digitale technieken beperkt. Hoewel in zowel de Verenigde Staten als in Frankrijk het internet beschouwd wordt als een efficiënte manier om geestesziekte-gerelateerde informatie beschikbaar te stellen, hebben $\mathrm{NIMH}$ en HAS twee belangrijke uitdagingen. Ten eerste moeten zij rekening houden met mensen die een beperking hebben of die verouderde en/of eenvoudige technologie gebruiken. Ten tweede moeten zij rekening houden met een sociaal-professioneel en cultureel klimaat waar psychiatrische benaderingen continu bekritiseerd worden en waar 
belangrijke worstelingen tussen diverse soorten professionals op het gebied van mentale gezondheid plaatsvinden. Om te begrijpen hoe deze overheidsinstanties in staat zijn overtuigend online expertise met betrekking tot bipolaire stoornis te bepalen, heb ik een innovatief methodologisch raamwerk gebruikt. Dit raamwerk stelde mij in staat om hun online platformen te benaderen als een complexe set van publieke performances. De bevindingen laten zien dat zowel NIMH als HAS terughoudend zijn als het aankomt op het gebruik van het internet en vaak voor niet-interactieve online platformen en statische digitale vormen kiezen, zoals PDF-bestanden en online tekst. Op deze manier wordt de kennis die beschikbaar is over bipolaire stoornis afgeschilderd als accuraat en stabiel, terwijl er daarnaast verschillende significante veranderingen in de conceptualisering van deze conditie doorgevoerd worden. Hoewel de performatieve technieken die zij gebruiken vergelijkbaar zijn, verschillen de MIMH en HAS in de manier waarop zij focussen in relatie met bipolaire stoornis. Ik beargumenteer dat dit verschil ontstaan is door de verschillende doelen die zij moeten nastreven, als gevolg van grootschalige veranderingen in de geestelijke gezondheidszorg in beide landen.

Hoofdstuk drie concentreert zich op mensen die gediagnostiseerd zijn met een bipolaire stoornis en de verschillende manieren waarop zij online expertise uitoefenen. Ik laat zien dat medische perspectieven op de effectiviteit van de therapieën voor deze conditie hun weg vinden via wetenschappelijke publicaties naar de (potentiele) ontvangers van deze behandelingen, die vervolgens deze kennis transformeren door hun online ontmoetingen. Deze conclusie is gebaseerd op een analyse van twee typen data: academische artikelen en samenvattingen met een hoge citatiescore en de online bijdragen van mensen gediagnostiseerd met bipolaire stoornis op fora en blogs. De bevindingen laten zien dat laatstgenoemden noties van onzekerheid, complexiteit en individualisering die de huidige medische perspectieven op het behandelen van bipolaire stoornis karakteriseren, zich toe-eigenen om verschillende praktische doelen te realiseren. Online blogs en fora maken een longitudinale accumulatie van tal van inzichten op dezelfde online ruimten mogelijk. Dit betekent, zo beargumenteer ik, dat mensen die gediagnostiseerd zijn met bipolaire stoornis verder kunnen gaan dan het uitoefenen van 'leken-expertise' door bij te dragen aan wat ik 'digitaal-geïnformeerde hypotheses' over de effectiviteit van een behandeling noem. Echter voordat deze hypothesen tot nieuwe inzichten leiden die medici in beschouwing kunnen nemen in het voorschrijven van medicijnen, moeten ze door wetenschappers onderzocht worden. Dit laat zien dat de mate waarin mensen die gediagnosticeerd zijn met bipolaire stoornis zich kunnen herpositioneren vis-a-vis medici middels zulke bijdragen, beperkt is.

Hoofdstuk vier onderzoekt de online en offline activiteiten van twee individuele bloggers. In een tijd waarin mensen aangemoedigd worden om informatie in te winnen over hun gezondheid en om daar verantwoordelijkheid over te nemen, laat ik zien dat 
deze bloggers veel invloed hebben door handig gebruik te maken van het internet. Door het verkrijgen en bepalen van interactionele expertise hebben zij het voor elkaar gekregen om belangrijke relaties te ontwikkelen met medici en mensen met bipolaire stoornis, die gretige lezers zijn van hun blogs. Aan de ene kant geeft de diagnose hen een mate van legitimiteit onder gediagnostiseerde mensen en hun families. In combinatie met hun slimme gebruik van het internet heeft dit hen in staat gesteld een groot publiek aan te trekken. Aan de andere kant hebben zij door het ontwikkelen van medische kennis en het verkrijgen van online populariteit zichzelf kunnen positioneren als vertegenwoordigers van mensen die gediagnostiseerd zijn met bipolaire stoornis, en zijn zo interessante medewerkers geworden voor wetenschappers en medici. Ik beargumenteer dat vanwege deze verschillende eigenschappen en door de bemiddeling die zij doen tussen mensen die gediagnostiseerd zijn en medici, dat deze bloggers zelf een nieuw soort belanghebbenden zijn geworden, wat ik 'online expert mediators' noem. De reputatie die zij genieten onder mensen gediagnostiseerd met bipolaire stoornis die geen medische training hebben genoten, is zonder precedent. Toch is deze positie niet ontstaan door subversief gebruik van het internet, maar door de strategische samenwerking tussen deze bloggers en 'traditionele' experts. Door te bestuderen hoe zij interactionele expertise bepalen, maakt dit hoofdstuk ook een theoretische bijdrage. Het laat zien dat dit concept een sterker bi-directioneel karakter heeft dan haar voorstanders (Collins \& Evans, 2002) hadden voorgesteld, en dat het de belangrijke effecten benadrukt die het medium heeft op de manieren waarop deze specifieke variant van expertise zich manifesteert.

In hoofdstuk vijf onderzoek ik hoe de ontwikkeling van 'leken-expertise' beïnvloed wordt door de huidige tendens om die gezondheids-gerelateerde aspecten te benadrukken die mensen van elkaar onderscheiden, en de drijfveer om personen verantwoordelijk te maken voor hun eigen gezondheid. Dit is belangrijk, aangezien lekenexpertise een collectief concept is. De ontwikkeling van leken-expertise is afhankelijk van de bereidheid van mensen om hun inzichten met anderen met dezelfde diagnose te delen. Het kan worden verworven als individuen in staat zijn om medische perspectieven te combineren met kennis verworven door het reflecteren op hun persoonlijke ervaringen en uit de strategieën die andere mensen delen. Door het gedrag van online bijdragers, die gediagnosticeerd zijn met bipolaire stoornis, te bestuderen, laat ik zien dat ze solidair zijn met anderen met wie ze belangrijke overeenkomsten delen. Daarbij ontwikkelen ze een nieuw type subgroep dat ik 'digitale biogemeenschappen' noem. Deze gemeenschappen ontstaan als mensen worden samengebracht door een gemeenschappelijke diagnose en door een toenemend aantal andere relevante gelijkenissen, zoals persoonlijke waarden en voorkeuren en een gemeenschappelijk idioom met betrekking tot hoe zij in de praktijk omgaan met de technologieën van online fora. Hoewel hieruit blijkt dat het internet de ontwikkeling van een nieuw collectief mogelijk heeft gemaakt met betrekking tot het vaststellen van expertise, zijn digitale biogemeenschappen gebaseerd op praktijken 
van inclusie en uitsluiting. Uit de bevindingen in dit laatste empirische hoofdstuk blijkt verder dat het vaststellen van solidariteit en lekendeskundigheid nauw met elkaar zijn verbonden, aangezien online bijdragers verschillende kosten maken en affectieve arbeid verrichten om hun kennis te delen met mensen die daar behoefte aan hebben. Zo positioneren verschillende individuen zich niet alleen als lekendeskundigen in specifieke contexten, maar dragen ze ook bij aan de collectieve ontwikkeling van lekenexpertise, omdat nieuwe kennis wordt gedistilleerd uit de verschillende praktijken waarmee zij informatie delen. Een opmerkelijke bijdrage die dit proefschrift daarom maakt, is dat het laat zien dat, ondanks de vrees dat een te sterke focus op individualisering in de gezondheidszorg de solidariteit in gevaar zou brengen, mensen die gediagnosticeerd zijn in staat blijven hun conditie relationeel te begrijpen en in een context te plaatsen middels het uitwisselen van ervaringen met verschillende mensen in hun leven. Bovendien slagen ze er via hun online uitwisselingen in om de identiteit van een kwetsbaar persoon die hulp nodig heeft af te zweren en hun vermogen om anderen te helpen en te ondersteunen te tonen, al is het maar voor even.

In het afsluitende hoofdstuk denk ik na over de betekenis van mijn bevindingen door ze te beschouwen tegen de achtergrond van huidige ontwikkelingen op het gebied van data-analyse en kunstmatige intelligentie. Enthousiaste aanhangers van kunstmatige intelligentie zijn van mening dat algoritmen en digitale technologieën de bevoorrechte posities die mensen lange tijd hebben gehad in de ontwikkeling van kennis kunnen overstijgen. Hiermee zaaien zij twijfel over de betekenis en relevantie van menselijke expertise. Dit proefschrift heeft echter aangetoond dat contextgevoeligheid en affectieve arbeid, in tegenstelling tot bovengenoemde verwachtingen, een belangrijke rol spelen bij het ontwikkelen en vaststellen van deskundigheid. Substantiële kennis van bipolaire stoornis moest door online bijdragers gecombineerd worden met relevante inzichten over socio-culturele en persoonlijke factoren. Op deze manier begrijpen mensen gediagnosticeerd met een bipolaire stoornis hun aandoening op een manier die is gevormd door de wijze waarop de mentale gezondheidszorg is georganiseerd in de landen waarin zij wonen, door de verwachtingen van medische professionals, familieleden, werkgevers en vrienden en door aspecten van hun leven die ze waardevol vinden en die ze, ondanks hun ziekte, willen verdedigen. Uit de hier gepresenteerde bevindingen is ook gebleken dat deskundigheid sporen bevat van belangrijke normen en waarden.

Veel wetenschappers en sociale commentatoren vrezen dat de tendens om mensen verantwoordelijk te maken voor hun gezondheid ertoe leidt dat gezondheidszorg verstrekt wordt op basis van verdienste. Echter een belangrijke bijdrage van dit proefschrift is dat veel online bijdragersbelangrijke gevoelens van welzijn ontlenen aan hun vermogen om anderen te ondersteunen en dat het delen van hun soms lastige situatie deze draaglijker maakt. Solidariteit is daarom een waarde die verder onderzoek verdient met betrekking 
tot het ontwikkelen en vaststellen van deskundigheid. Er moet ook meer aandacht worden geschonken aan de affectieve praktijken die nodig zijn voor de productie van epistemische beweringen en deskundige aanbevelingen, aangezien de bevindingen in deze studie aantonen hoe belangrijk 'emotioneel management' is voor interacties tussen mensen met verschillende soorten kennis en behoeftes en die verschillende doelen nastreven.

Een andere belangrijke bijdrage van dit proefschrift is dat het toont hoe invloedrijk culturele factoren blijven wanneer deskundigheid over bipolaire stoornis online wordt uitgeoefend. Door het vergelijken van Amerikaanse en Franse stakeholders, heeft de analyse een aantal belangrijke overeenkomsten en verschillen blootgelegd. Beide overheidsinstanties gebruiken soortgelijke performatieve technieken op hun online platforms en mensen gediagnosticeerd met bipolaire stoornis in beide landen hebben bijgedragen aan de ontwikkeling van wat ik 'digitaal-geïnformeerde hypotheses' heb genoemd. Zij hebben zich ook beziggehouden met solidaire praktijken. Desalniettemin tonen de bevindingen ook dat online bijdragers in de VS hun inzichten liever op blogs delen terwijl in Frankrijk online fora populairder zijn. Hoewel dit kan komen door het wisselende niveau van online zichtbaarheid van de blogs en fora, is er meer onderzoek nodig om beter te begrijpen wat de oorzaak is voor dergelijke verschillen. Het aanmoedigen van mensen om actief betrokken te raken bij het managen van hun gezondheid in combinatie met de mogelijkheid dat zij producenten worden van gezondheidsgerelateerde informatie door het gebruik van interactieve online platforms, heeft tot de ontwikkeling van een nieuw en zeer succesvol type ondernemers in de VS geleid, die ik 'online expert bemiddelaars' noem. Het ontbreken van deze vorm van ondernemende subjectiviteitin het Franse online Mental Health-landschap kan te wijten zijn aan een minder uitgesproken focus op individueel ondernemerschap in Frankrijk, of aan het feit dat Franse medische professionals erin zijn geslaagd hun gezag te behouden en meer persoonlijke relaties met patiënten te onderhouden. Een ander belangrijk cultureel onderscheid dat dit proefschrift heeft benadrukt, verwijst naar de verschillende benaderingen van en oriëntaties op bipolaire stoornis. De twee overheidsinstanties die ik bestudeerd heb, her-conceptualiseren bipolaire stoornis op verschillende manieren. Waar de een een neurologische begrip benadrukt, legt de ander de nadruk op haar degeneratieve en zeer suïcidale karakter. Terwijl veel Franse online bijdragers gediagnosticeerd met deze aandoening zich bezighouden met online uitwisselingen met als doel te leren hoe zij beter met deze aandoening kunnen omgaan in de context van een rijk professioneel en persoonlijk leven, waren veel online deelnemers in de VS werkloos of hadden moeite hun werk te behouden. Bovendien leek deze laatste groep vaker moeizame familierelaties te hebben en aan minder sociale activiteiten deel te nemen dan hun Franse tegenhangers. Er is daarom meer onderzoek nodig om te 
begrijpen wat de oorzaken zijn voor deze sociale verschillen jegens bipolaire stoornis en welke maatregelen het meest effectief zijn bij het aanpakken ervan.

Over het algemeen heeft dit proefschrift aangetoond dat het online uitoefenen van expertise geen eenvoudig proces is waarbij offline praktijken en benaderingen gemakkelijk kunnen worden geüpload naar verschillende online ruimtes, maar dat dit veel werk, nieuwe vaardigheden en soms nieuwe of verschillende samenwerkingen tussen belanghebbenden vergt. Velen hoopten dat het internet mensen die gediagnosticeerd zijn meer zou betrekken in het managen van hun gezondheid en hen beter in staat zou stellen meer evenwichtige relaties met medische professionals te ontwikkelen. Echter, de bevindingen gepresenteerd in dit proefschrift suggereren dat dergelijke opties alleen beschikbaar zijn voor bepaalde individuen in specifieke contexten. Het werd duidelijk dat mensen die gediagnosticeerd zijn zich op genuanceerde manieren verhouden met de medische inzichten die voor hen beschikbaar zijn, omdat ze de inzichten niet zonder meer accepteren of zich er automatisch tegen verzetten. In plaats daarvan maakten ze ze zich deze inzichten op creatieve manieren eigen en pasten ze deze aan hun specifieke doelen en voorkeuren aan. Bovendien heeft het internet de ontwikkeling van een breed scala aan uitwisselingen vergemakkelijkt, variërend van vrij korte en vluchtige interacties tussen individuen die geïnteresseerd zijn in een paar specifieke onderwerpen, tot de opkomst van de zeer populaire en invloedrijke online expert mediators en de ontwikkeling van digitale biogemeenschappen van mensen die door een groeiend aantal gemeenschappelijke delers zijn samengebracht en bijeengehouden.

Het internet wordt door velen benaderd als een snelle technologische oplossing, als een medium waarmee geestelijke gezondheidsgerelateerde informatie en zorg op een kosteneffectieve manier kunnen worden verstrekt aan een groot aantal mensen. Uit de bevindingen van dit proefschrift is echter gebleken dat dergelijke benaderingen onvermijdelijk mislukken als de sociale en culturele context waarin het internet wordt gebruikt onvoldoende in overweging wordt genomen. Tegelijkertijd geeft dit proefschrift aan dat de vrees dat het gebruik van internet negatieve gevolgen zou hebben voor de gezondheid en het welzijn van mensen die gediagnosticeerd worden door hen bloot te stellen aan onnauwkeurige informatie en/of door het verhogen van de risico's van moeilijke relaties met hun medische professionals, niet altijd gegrond zijn. Dit betekent echter niet dat dit medium niet tot nieuwe uitdagingen zal leiden. Nieuwe benaderingen en beleidsmaatregelen zijn nodig om deze uitdagingen beter aan te pakken en deze kunnen voornamelijk worden ontwikkeld door aandacht te schenken aan de specifieke manieren waarop verschillende soorten gebruikers omgaan met de mogelijkheiden die verschillende online platformen hen biedt. Bovendien moeten er belangrijke veranderingen optreden in het gedrag van relevante betrokkenen, zodat het internet zijn potentieel kan bereiken om de betrokkenheid van patiënten te 
bevorderen en de kwaliteit van hun relaties met medische professionals te verbeteren. Waar gediagnosticeerde mensen beter vertrouwd moeten raken met wetenschappelijke benaderingen en methodes, moeten wetenschappers en medische professionals de tijd en de kans krijgen nauwere relaties te onwikkelen met hun patiënten en respondenten in hun onderzoek. De bevindingen in dit proefschrift suggereren dat gediagnosticeerde mensen in staat zijn om te gaan met bronnen van onzekerheid of dubbelzinnigheid, en dat zij lagere drempels voor de effectiviteit van de behandeling kunnen accepteren, mits de manier waarop zij hierover geïnformeerd worden niet paternalistisch is, maar uitnodigt tot een open dialoog. 
